Egyptian Journal of Archaeological and Restoration Studies
An international peer-reviewed journal published bi-annually
www.ejars.sohag-univ.edu.eg

Original article

\title{
THE GREAT MOSQUE OF TIZNIT: AN ARCHAEOLOGICAL ARCHITECTURAL STUDY
}

Aglan, A.

Islamic Archaeology dept, Faculty of Archaeology, Sohag Univ., Sohag, Egypt

E-mail address: ameraglan@arch.sohag.edu.eg

\begin{tabular}{|c|c|}
\hline Article info. & EJARS - Vol. 11 (1) - June. 2021: 53-70 \\
\hline Article history: & Abstract: \\
\hline Received: $23-9-2020$ & The great mosque is an important monument in Tiznit because of \\
\hline Accepted: $17-3-2021$ & its archaeological foundations, historical value, and significant \\
\hline Doi: 10.21608/ejars.2021.179497 & $\begin{array}{l}\text { scientific prestige. It has all features, including its architectural } \\
\text { elements and units, to play its due role. For example, it includes } \\
\text { riwaqs for prayer, a minbar (pulpit), a mihrab, a minaret, etc. The } \\
\text { Mosque comprises a court, four riwaqs, a room for orator, a room } \\
\text { for pulpit, and a minaret. An ablution fountain was attached to the } \\
\text { southeast side. The walls were built using Tapia (compressed dry } \\
\text { mud), and the ceilings were made of wood. The present study } \\
\text { aims to highlight the archaeological and architectural - in addition }\end{array}$ \\
\hline Keywords: & to the religious and scientific- values of the Mosque. This issue \\
\hline Mosque & helps keep the mosque with its original architectural elements and \\
\hline Tiznit & enhance the tourist attraction of the city. Using the historic, desc- \\
\hline Islamic Architecture & riptive, and analytical approaches, the study describes, documents, \\
\hline Morocco Architecture & mosque. \\
\hline
\end{tabular}

\section{Introduction}

Tiznit is a town in the southern Moroccan region of Souss-Massa. Tiznit is a Berber (Tamazight) word with no clear signifycance. Therefore, various hypotheses have been made for the linguistic implication of the word. Tiznit has a $\sin$ that equals $z \bar{a} y$. This alternation is familiar in the Berber dialects. Thus, it is altered from "asny", which is an agricultural area in the grand atlas. Another example is "tisnit" that is altered into "Tiznit", which has a water-hole on which agriculture relies. "tisi n ayt", i.e. the land irrigated with the water of the waterhole is mitigated to "Tisnit" and turned into "Tiznit" [1]. Tiznit was establ-ished in a valley called "Azgar"; a Berber term for the valley or the flat area in comparison to the surrounding high areas. It is a flat valley with a slight rise. It is worth noting that the valley of Tiznit has important ground- water and many waterholes. The city of Tiznit was established on a waterhole, known as the ancient or blue waterhole [2,3]. The great mosque of Tiznit is a scientific and religious center in Sous. The first hint was received to the old mosque in the context of jurisprudential issue in (12A.H/ 18A.D) century. Then it was rebuilt by the leader Sáed 'Al-kelouly in (1313A.H/1896 A.D) after the collapse of the old mosque and its simple minaret that was located on the present fountain. Sáed built external walls and roofed the first row. After his death, the construction of the mosque was not completed, and the minaret was left without daubing. In (1321A.H./1903A.D.), the leader Hamo 'Al-tiznity added the second and the third rows from the direction of the Qibla, and the minaret was not daubing until (1345A.H./1926A.D.) [4]. The mosque 
is located in the Id Dalha district near the Blue Waterhole and the Kasbah of Aghnaj. It is the primary kernel and the spiritual, political, and economic center of the city [5], fig. (1-a). The shape of buildings and the organization of alleys show that the Id Dalha and Id Ougfa districts are the oldest in the city [6]. The mosque with its main (western) façade overlooks the hall of the mosque on Al-bashaweya Street. To the north, it overlooks the Blue waterhole street, which separates it from the Kasbah of Aghnaj. To the east, it overlooks a space leading to the ablution and some neighboring buildings. To the south, it overlooks a walled space, fig. (1-b).
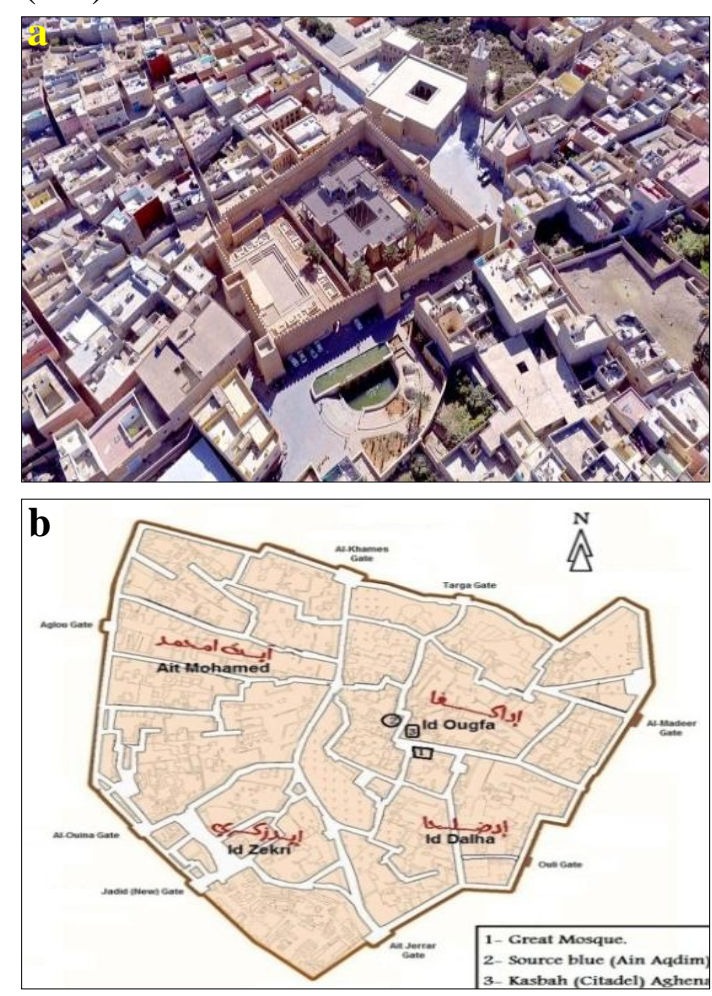

Figure (1) Shows a. Tiznit city \& location of great mosque, (After, Tiznit collective memory, 2009), ‥ site view of great mosque, (After Naji \& David, 2016).

\section{Architectural Description}

The mosque was built on a regular area of $891 \mathrm{~m}^{2}$ with $33 \mathrm{~m}$. long and $27 \mathrm{~m}$. wide. Its walls are $5.20 \mathrm{~m}$. high and $1 \mathrm{~m}$ thick. It consists of a court, four riwaqs, a room for orator, a room for pulpit, and a minaret. An ablution was attached to the southeast side, fig. (2).

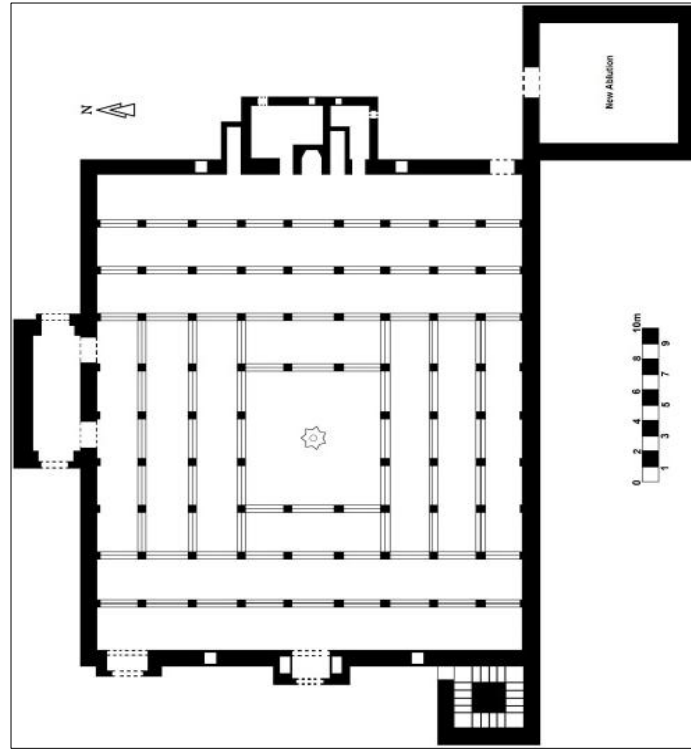

Figure (2) Shows lan of great mosque-Tiznit.

\subsection{External description}

\subsubsection{Western façade}

It is the main façade, fig. (3), it overlooks Al-bashaweya Street. It is $27 \mathrm{~m}$. long, 5.20 $\mathrm{m}$. high, and $1 \mathrm{~m}$. thick. It contains two distinguished entrances. The first entrance is in the middle. It is distinguished from the façade about $1.16 \mathrm{~m}$. It is $3.80 \mathrm{~m}$. wide and $4.34 \mathrm{~m}$. high. In the middle, it contains a door opening of $1.60 \mathrm{~m}$. wide and $2.65 \mathrm{~m}$. high topped by a pointed horseshoe-arch and shutterd by two wooden shutters. Moreover, the entrance façade is decorated with a stone frieze. It is crowned by rows of green-glazed pantiles. The second entrance is at the end of the north side of the western façade. It is distinguished from the façade $0.70 \mathrm{~m}$. It is $3.80 \mathrm{~m}$. wide and $3.85 \mathrm{~m}$. high. In the middle, it contains a door opening of $1.60 \mathrm{~m}$. wide and $2.65 \mathrm{~m}$. high topped by a pointed horseshoe-arch and shutterd by two wooden shutters. The entrance façade is decorated with a stone frieze. It is crowned by rows of greenglazed pantiles. Some old photos and old sketches of the mosque illustrate that this entrance was added later because they did not contain it. I think that this entrance was dedicated to the entrance of the women as it leads to the riwaq facing the qibla riwaq and was surrounded in the part next to this door with a wooden fence dedicated to the prayer of women. The façade contains two square windows that 
opened on $3.20 \mathrm{~m}$. high. Each side is 0.87 $\mathrm{m}$. long. They are topped by rectangular wooden lintels, on which steel bars were fixed from outside. One window opens in the southern end of the façade next to the minaret, whereas the other opens in the northern side on the space between the entrance blocks.

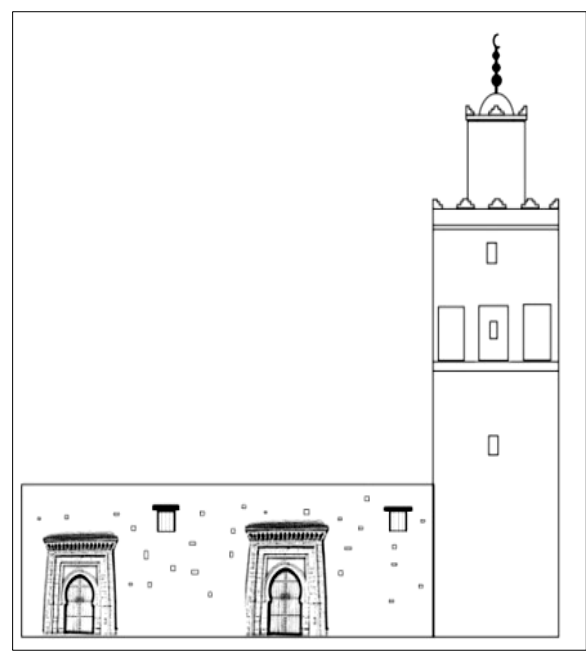

Figure (3) Shows front elevation (main façade).

\subsubsection{Northern façade}

It overlooks the Blue waterhole street, fig. (4-a). It is $33 \mathrm{~m}$ long, in the middle, there is a building block distinguished from the façade of $3.90 \mathrm{~m}$. and $9.43 \mathrm{~m}$. wide. It has two entrances. One entrance is a rectangular opening of $1.60 \mathrm{~m}$ wide and $2.40 \mathrm{~m}$. high. It is topped by a segmental arch. The jambs and arch of the entrance were built from stone. Moreover, there is a wooden lintel above the entrance that is shuttered by two wooden shutters. The other entrance is on the eastern side. It is similar to the entrances that of the western side. It contains a door opening of $1.60 \mathrm{~m}$. wide and $2.65 \mathrm{~m}$. high topped by a pointed horseshoe arch and shuttered by two wooden shutters. Moreover, the entrance façade is decorated with a stone frieze. It is crowned by rows of green-glazed pantiles, fig. (4-b).
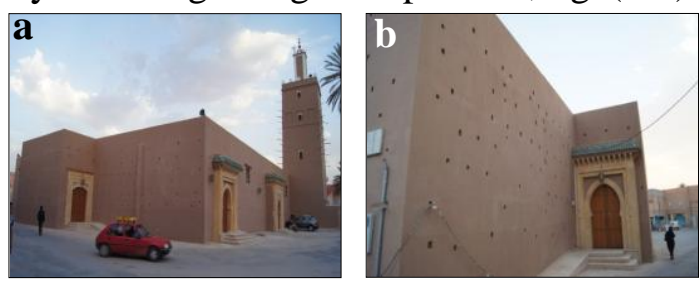

Figure (4) Shows $\underline{\text { a. }}$ great mosque of Tiznit, $\underline{\mathbf{b}}$. the Eastern entrance in the Northern Façade.

\subsubsection{Eastern façade}

It is $27 \mathrm{~m}$. long, in the middle, there is a building block distinguished from the façade $4 \mathrm{~m}$. It is $8 \mathrm{~m}$. wide. Internally, the building block contains the room of orator, room of pulpit, niche of the mihrab, library and a room that may be used as a stockroom. At the end of the southern side of the façade, an opening links the inside of the mosque and the space overlooking the ablution. Moreover, the façade has two windows similar to the windows of the western façade.

\subsubsection{Southern façade}

This façade is long and contains no openings. In the western end, it ends with the minaret. Without the body of the minaret, the façade is $33 \mathrm{~m}$ long.

\subsection{Internal description}

Internally, the Mosque has a rectangular space from the east to the west. It is 31 $\mathrm{m} . \times 25 \mathrm{~m}$. It can be accessed through the first entrance of the western façade leading to a rectangular passageway of $1.80 \mathrm{~m}$. wide and $2 \mathrm{~m}$. deep. Behind the door, two recesses open on $0.32 \mathrm{~m}$. high. Each recess is $1 \mathrm{~m}$ wide and $2.50 \mathrm{~m}$. high. Moreover, each recess is topped by a semi-circular arch, fig. (5). The passageway is covered with a flat wooden ceiling, leading to the riwaq facing the qibla riwaq that can be accessed through the other entrance of the western façade. The inner of the mosque can also be accessed through the two entrances in the distinguished building block in the middle of the northern façade. They lead to a rectangular area of $2.75 \mathrm{~m}$. $\times 7.40 \mathrm{~m}$., and covered with a flat wooden ceiling, leading to the northern riwaq through two rectangular openings that measure $2 \mathrm{~m} \times$ $3.10 \mathrm{~m}$. They are covered by wooden lintels.

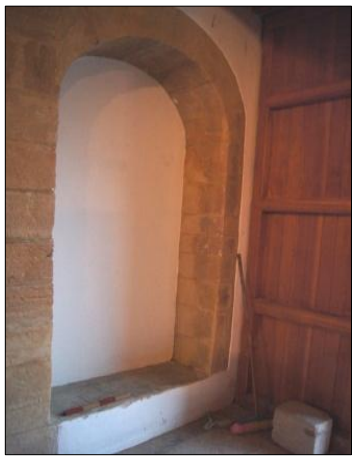

Figure (5) Shows the recess behind the main entrance. 


\subsubsection{The court}

The mosque surrounds a rectangular court of $8.67 \mathrm{~m}$. long and $7.33 \mathrm{~m}$. wide. Its floor, which is laid with Azulejos (Zellīj) tiles, is $0.10 \mathrm{~m}$. lower than that of the riwaqs. The court comprises a fountain in the form of an eight-star marble-covered, with a cylindrical marble basin in its center, fig. (6-a). The four riwaqs overlook the cort with an arcade of three pointed horseshoe arch, as well as wood and glass cover. The arcades end with stone cantilevers crowned with green-glazed pantiles, fig. (6-b).
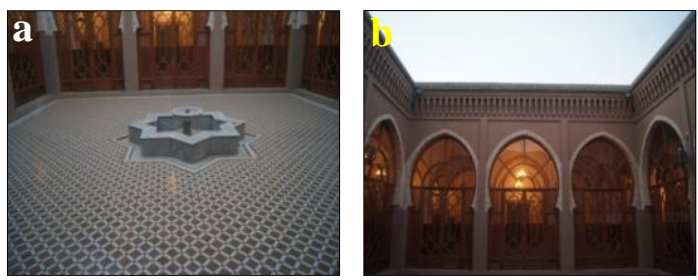

Figure (6) Shows a. the fountain in the middle of court, $\underline{\mathbf{b}}$. the court

\subsubsection{Qibla riwaq}

Qibla riwaq occupies a rectangular area that extends from the north to the south, fig. (7). It consists of three arcades, each arcade has eight pillars bearing nine arches of the pointed horseshoe arch type are parallel to the wall of the Qibla, fig. (2) qibla riwaq has a flat wooden ceiling, whose height is roughly $5 \mathrm{~m}$. above the floor of the mosque.

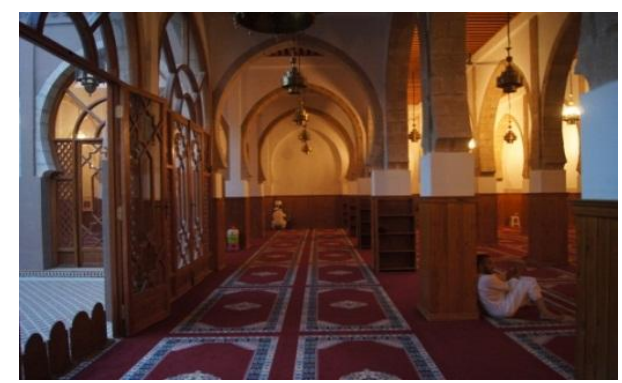

Figure (7) Shows arcades and aisles

\subsubsection{Mihrab}

Mihrab, which is in the center of the qibla wall, is a five-sided squinch, with a depth of $1.67 \mathrm{~m}$., a width of $1.25 \mathrm{~m}$., and a height of $2.16 \mathrm{~m}$. It crowned by a pointed horseshoe arch. It has no decorations. The arch and two spandrels of the mihrab is decorated by stucco braid, which surrounds the top of the mihrab, forming a mimahornament. Stucco geometrical ornament decorate the two spandrel, qibla wall above mihrab and the two entrances of room of orator and room of minbar, fig. (8).

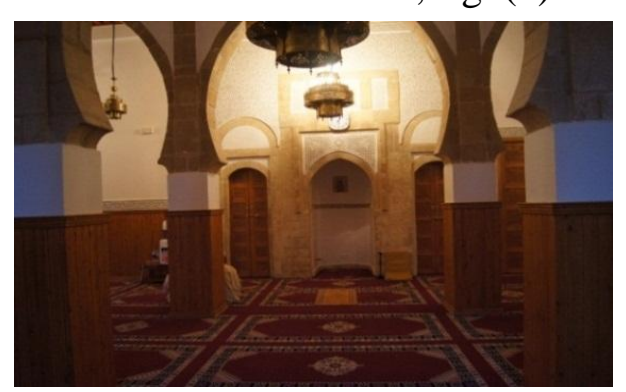

Figure (8) Shows the mihrab

\subsubsection{Room of minbar}

It is located to the south of the mihrab and opens onto qibla riwaq with a rectangular door opening of $0.80 \mathrm{~m}$. wide, and $2.10 \mathrm{~m}$. high. Segmental arch is above it, fig. (8), and two wooden shutters are shuttered on it, leading to the room of minbar, whose depth is roughly $2.60 \mathrm{~m}$. To the south of the room of minbar, there is a door opening with a width of $1.10 \mathrm{~m}$. and a height of $2.45 \mathrm{~m}$. as well as two wooden shutters, leading to a room with the shape of "L" letter and a depth of $3.50 \mathrm{~m}$. It containing a door opening in the southern side lead to outside with a width of $0.80 \mathrm{~m}$. and a height of $1.80 \mathrm{~m}$., and contains a rectangle window of $0.50 \mathrm{~m}$. width and $0.70 \mathrm{~m}$. height. It might be used as a store for the mosque or a library.

\subsubsection{Room of orator (The khateeb rest)}

It is located on the north of the mihrab and opens onto qiblah riwaq with a door opening similar to that of room of minbar, fig. (8), leading to the interior of the rest, which occupies $3.50 \mathrm{~m}$. square area. It containing a door opening in the eastern side lead to outside with a width of 0.80 $\mathrm{m}$. and a height of $1.90 \mathrm{~m}$., and contains a rectangle window of $0.50 \mathrm{~m}$. width and $0.60 \mathrm{~m}$. height. It is covered with a flat wooden ceiling. On the north, there is a door opening with a width of 1 meter and a height of $2.10 \mathrm{~m}$., as well as two wooden shutters, leading to a rectangular room, It might be used as a store for the mosque or a library. 


\subsubsection{Western riwaq}

It is opposite qibla riwaq and forms a rectangular shape that extends from the north to the south. It consists of two arcades, arcade has eight pillars bearing nine pointed horseshoe arches are parallel to the Qibla wall, fig. (2). The riwaq is covered with a flat wooden ceiling.

\subsubsection{Side riwaqs}

They are the northern and southern riwaqs. Each riwaq consists of three arcades; each arcade has four pillars bearing five pointed horseshoe arches perpendicular to the qibla wall. They are covered with a flat wooden ceiling. There are also two arcades overlooks the court, one of the eastern side and the second of the western side. Each arcade has two pillars bearing three arches are parallel to the Qibla wall, fig. (2).

\subsection{Minaret}

It is located outside the prayer square adjacent to the walls of the mosque at the southern end of the western facade. Its design follows the model of the Moroccan minarets with a square projection, fig. (3, 4-a). Its total height from the ground level is approximately $24 \mathrm{~m}$. The first level is a square projection with side length $6 \mathrm{~m}$. and $17 \mathrm{~m}$. height. The minaret door is on the northern side of the first level. It is a rectangular opening with a width of 0.80 $\mathrm{m}$. and a height of $1.60 \mathrm{~m}$. It is topped with a segmental arch. The jambs and arch are built of stone. A wooden shutter closes on the door opening, fig. (9). At this level, eleven windows are opened to illuminate and ventilate the minaret staircase. Each side comprises three windows, but the eastern side involves two windows. Dimensions of each window are $0.40 \mathrm{~m} . \times 0.80 \mathrm{~m}$. Each side is decorated with three rectangular recesses whose dimensions are $1 \mathrm{~m} . \times 1.20$ $\mathrm{m}$. One of the aforementioned windows opens in the middle recess. A prominent frieze decorates the top of the first level, which ends with three serrated crests at each side, in addition to four serrated crests in the corners. Some wooden pieces from tree branches are fixed at a height of $6 \mathrm{~m}$ on the four corners of the minaret. The second level of the minaret, which is known as "Al-Jawsaq", is about $5 \mathrm{~m}$. height, and ends with one serrated crest at each side, in addition to four serrated crests in the corners. It is domed by a conical dome crowned with a pole, which is a metal pillar with three metal balls topped by a crescent.

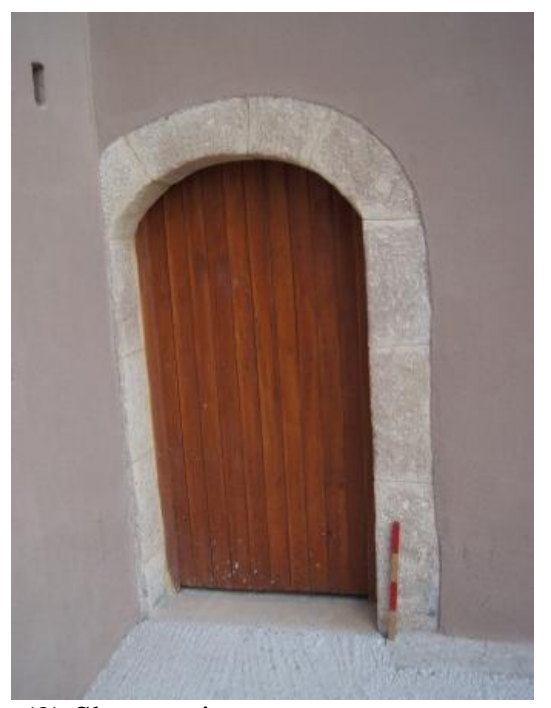

Figure (9) Shows minaret entrance.

\section{Analytical Study}

\subsection{Location of the mosque}

The Mosque is located in the Id Dalha district near the blue waterhole - the water source - and the Kasbah of Aghnaj, fig. (1-a). The importance of relationship of adjacency between the mosque, the waterhole and the Kasbah is illustrated in the framework of the urban dimension of the city. Therefore, the establishment of the city was related to water because water holes are a factor of attraction and stability for many tribes in the region, and Tiznit was established on a blue waterhole, and the first nucleus of the city was in the $I d$ Dalha and Id Ougfa districts - as mentioned - therefore, there must be a mosque to serve these districts. The site was located near the blue waterhole to easily supply with water required for ablution, drinking and other, and this location is near the city center, so that it is close to every place in it to easily reachable. It is a continuation of the phenomenon of mosques locations in the Islamic city since the era of the 
Prophet. And when the leader Muhammed Aghnaj campaigned on Sous in (1225A.H./ 1810A.D.) he built a Kasbah in Tiznit called the Kasbah of aghnaj, and selected its site in the city center near the mosque. This site allows commander to better manage, control the city and extend its security. In addition better secure for the governor due to near his headquarter from the mosque. Also, the relationship between the commander headquarter (Kasbah of aghnaj) and the mosque is a continuation of the phenomenon of adjacency among the emirate house, and the mosque, which started in the city since the era of the Prophet.

\subsection{Benefit elements}

\subsubsection{Riwaqs}

The mosque's design manifests that the riwaqs occupy most of the mosque's area, fig. (2). Accordingly, the major area is devoted to accommodating a large number of worshipers, because there are no other left areas except a small area for the court. The planning of the mosque is four adjacent riwaqs as if they are only one. Perhaps, this design considers prayer riwaq as a major place for prayer in the mosque, such as Al-Masjid an-Nabawī (The Prophet's Mosque) during the era of the Prophet and The Rashidun Caliphs. The largest riwaq is the qibla riwaq, whose area is consistent with its purpose and the width is larger than the depth that is the most appropriate for prayer riwaqs because it allows several worshipers to stand in the first rows. This corresponds to the reward of the first rows, as stated in the Prophet's Sunnah [7]. Thus, this app-roach is more preferable than the circle, the octagon, and the hexagon, which do not allow several worshipers to stand in the row [8]. To provide more space for the worshipers, the depth of the mihrab squinch reached $1.67 \mathrm{~m}$. This depth, as well as the wide opening, allows the Imam to stand inside the squinch, be visible to the worshipers, and to provide a row behind for the worshipers. This maximizes the number of worshipers in the qibla riwaq. The architect managed to achieve this depth in the mihrab through the prominence of the mihrab squinch outside the qibla wall. The depth of niches is a phenomenon prevalent in the mosques of Morocco and Andalusia $^{(a)}$ [9]. The mihrab is polygonal. The polygonal design of mihrabs in the mosques of the Islamic west reflects the Andalusian influence inspired by the sevensided mihrab of the Mosque of Cordoba [10]. The architect was keen to provide special design for sound in the qiblah riwaq to facilitate contact between the preacher or the imam and the worshipers. Moreover, the depth of the mihrab squinch helped amplify the imam's voice [11], which several worshipers hear. The mosque has no pew (muezzins' bench) because the mosque's architectural design involves connected riwaqs around a small court as if they are one riwaq whose area allows the imam's voice to reach all worshipers directly and clearly without the need for muezzins to repeat what the imam says. Lack of pew is the system prevalent in all Moroccan mosques. Mosques of the Islamic west knew the pew in the Ottoman era [12]. Before that each mosque comprised four muezzins stand behind the imam, and the first's voice reaches the second whose voice reaches the third whose voice reaches the fourth muezzin [13]. The northern part of the western riwaq was surrounded by a wooden fence. It might be dedicated to women's prayers, and had a special entrance on the western façade, as previously mentioned, to achieve privacy for women during their prayer.

\subsubsection{Minaret}

Before we conclude our discussion about the minaret, we would like to point out the purpose of implanting wooden pieces in the corners of the minaret. Is this a mutual effect with the African architecture, as some have mentioned? And according to local legend, wood was used so that the souls of the dead would gather and rest 
there [20]. Or is it not an African influence, but is merely a technique related to the fact that the minaret that was built from the Tapia had witnessed successive modifications and restorations [4] that it was used to ascend the minaret during restoration? In addition, I would like to refer that putting wooden pieces in the minarets and the walls of the mosques is a well-known phenomenon that was used in the style of Sahel mosques, for example, in Mali mosques and they were used in ascending during the restoration, fig. (10). But by comparing the size of the wooden pieces in the minaret of the Tiznit Mosque and its counterpart used in Mali mosques, we find that the woods in minaret of Tiznit are small and do not bear one person or more to restore it. These wooden pieces were found in the corners of the minaret only and at a great height from the surface of the earth. Hence, the size, number, position, and distribution of the wood pieces make us exclude that they were used during the restoration, and I think it used as a local legacy.

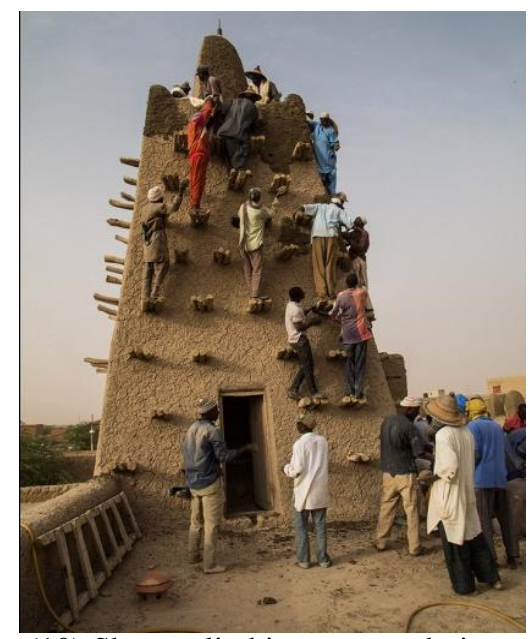

Figure (10) Shows climbing on wood pieces during restoration - Djinguereber mosque in Timbuktu, Mali. (After, https://www.flickr. com/ photos/minusma/32239632874, 4/03/2020)

\subsubsection{Room of the minbar}

It is not preferable that the minbar to be large in order not to occupy a large space of the riwaq of prayer. For this reason, scholars prefer removable minbars [21]. The great mosque of Tiznit, like other mosques in the Islamic West, contained a removable wooden minbar. The movement of the minbar requires some architectural requirements represented in the following: the room of the minbar has to be on the right of the mihrab, all minbars are made of wood, and a set of wheels that run on iron bars are fixed with their bases to facilitate their entry and exit to and from the room of the minbar. And when the minbar is inserted in his room the ranks of the worshipers are upright behind the Imam [13]. The size of the minbar was also relatively small as to facilitate its movement and to be suitable for the room of the minbar. The small size of the minbar also helped in achieving a better view of the orator without overwhelming the worshipers sitting in the first rows. It is appropriate that the minbar does not rise above the level of the floor except to the extent that the worshipers are allowed to see the orator, as it was found that the largest viewing angles are in the first row, which should not exceed 45 degrees in order not to cause troubles for the seated worshipers as a result of raising their heads during the sermon. Considering that the distance between them and the orator is equivalent to two rows (approximately $2.40 \mathrm{~m}$.), then the orator's head is at a height of $2.40 \mathrm{~m}$. from the sight level of the seated whose height is about $0.80 \mathrm{~m}$., and if we assume that the average length of the orator is $1.75 \mathrm{~m}$., his height is at the highest level of the minbar $(2.40+0.80)-1.75=1.45$ m. [16], fig. (11).

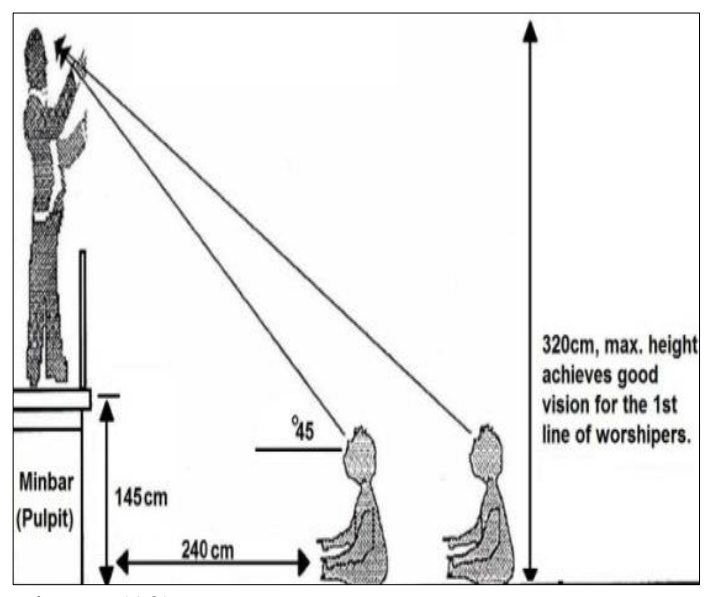

Figure (10) Shows preferred height of the Minbar. (After, Nofal, 1999). 


\subsubsection{Ablution}

The ablution fountain lost its archaeological character because of many modifications and restorations. In the mosques of Morocco, the ablution fountain was usually outside but near the mosque's corridor, as shown in the mosque of Tiznit where the ablution fountain was established outside the mosque to the southeast side according to fiqh judgments that called for the purity of the mosque and prevent bad smells from to the worshipers as Tiznit has northwestern wind. Additionally, there was an opening in the southern part of the qibla wall to facilitate access to the ablution fountain.

\subsubsection{Room of orator}

The room of orator is one of the benefit elements that have been attached to the mosques in Mashriq and Maghreb. It had been established close to the minbar on which the orator stands and mihrab where he prays. [22]. Thus, it is customary in the Maghreb that the room of orator is located behind the qibla wall and has a door on the left of mihrab. The function of the room of orator controlled its area; its area is $3.50 \mathrm{~m}^{2}$. in Tiznit mosque. This area is appropriate for the furniture, such as a sofa, a small wooden cupboard for the Mus'hafs and books that helps the orator take a rest and prepare sermon. The window and two entrances provided the ventilation and lighting inside this room [23]. The function of the orator room also affected the number of its entrances, as it involves two entrances: The first opens outside the prayer hall and the second opens inside qibla riwaq next to the mihrab. The two entrances enable the orator to enter the room, prepare his sermon and reach the minbar without passing through the worshipers, which is disapproved in jurisprudence.

\subsubsection{Library}

The library is one of the important benefit elements of the religious buildings especially that doing educational function, because it is the place where students go to get books and literature [22]. The great mosque of Tiznit was an important scientific center in Sous. Many scholars were in the Great Mosque, including Alhassan ibn Alțifür Alsamkūney and Mohammed ibn Ahmed Alagraboy. The scientific famous of the mosque was associated with great teacher ibn Altaifür (1267A.H/ 1860A.D). because of him, the study was systematical in the mosque, and students increased from everywhere. In the end of his life he donated most of his books - more than 400 books to the mosque library. The scientific activity of the mosque has increased, but its important feature was the proliferation of the regular courses that it competed with the well-known traditional schools of the time, such as Adouz, Bounoámane, and Azreef. The teacher Mohamed Albaz played a considerable role in improving the methods and curricula of teaching the different sciences from joining the Mosque to its transformation into a branch of Taroudant Institute in (1375A.H./1956A.D.) [4]. The library located behind Qibla wall - as the usual in Morocco's mosques. We get to it from entrance beside the mihrab, to be close to Qibla riwaq where convening of lessons to be books close to the teachers and the students.

\subsection{Elements of construction}

\subsubsection{Foundations}

Structurally, the foundations' function is to distribute and deliver the loads above to the appropriate soil layers without causing breakdowns or undesired pressures. According to the importance of the foundations in the durability of the building, the architect was clearly interested in it, as reflected by the use of durable building materials in building the foundations, such as stone, reed brick, mud, and clay if the stone is not available [24]. The nature of the land is related to the foundations. If it is rocky, the foundations are not dug deep. Unlike areas that do not have proximity to the level of rocky land or lack, they need deep foundations that may reach a level commensurate with the height of the constructed buildings to bear the weight on it whether the dead load caused by the 
buildings or the live load exemplified by whoever exploits its units. Thus, it remains to fulfill the function for which it was established [22]. Construction using the tapia needs to drill the foundations with a depth of $0.50 \mathrm{~m}$. Then, the foundations are built with irregular stones that are linked with a large amount of mortar, after which the construction of the walls begins.

\subsubsection{Bearing walls}

The constructor's desire to construct a mosque characterized by strength and durability has its effect on forming loadbearing walls. A form that is sought to achieve durability. Its bearing of dead weights is represented by the weight of the walls themselves and the coverage above them [24]. The walls of the mosque were constructed with a thickness of $1 \mathrm{~m}$. To increase the durability of the walls, pieces of wood with a length that does not exceed the width of the wall and are thin are added from time to time to the mixture. Other long, straight, or slightly twisted pieces are placed next to each other on the longitudinal extension of the wall [25]. To enhance durability, the walls are covered with an outer covering, which is often a thin layer of lime and sand, to protect from various weather conditions and to prevent water leakage inside the wall. To reduce the weight on the walls, the building ceiling materials used light construction materials, including wood. The openings were weaknesses points in the walls built with the tapia, so no windows were opened in the lower section of the walls of the mosque. Only four upper windows were opened: Two in the qibla wall and two in the western façade. In order to boost the durability of the walls of the mosque, a group of holes or gaps spread regularly or irregularly to ventilate the walls and minimize moisture. In particular, some of the materials that the tapia consists of are characterized by great ability to store water, while others are susceptible to bloating and rib vaulting according to the amount of water available in them. They are highly affected by the succession of wetness and drought [26].

\subsubsection{Columns and pillars}

From the beginning of the first half of the (6 A.H/12 A.D) century, the Moravids (alMurābițūn) introduced an important renewal of the structural elements carrying the religious buildings in Morocco and Andalusia. They used brick pillars as load-bearing elements that underpinned the arches instead of the stone or marble columns that were used at the time $[27,28]$. The pillars continued to be used during the Moaheds age and Marinids, especially in mosques, and in the Saadi buildings, the pillars were used side by side with the columns [13]. They were also used mainly in the Alawite mosques. In Tiznit mosque, the arcades consisted of rectangular pillars topped by ceiling bearing arches. The pillars and columns in the mosque have other functions besides their constructional function; including to initiate and pray to it is Sunnah, because it is used as a cover for the prayer (placing a concrete object in front of the one who prays). It is a place for some to lean, fig. (10). Shelves can be placed on them to put the Holy Qur'an and useful books. It also helps visualize and straightness the rows of pray [29].

\subsubsection{Arches}

In the mosque, pointed horseshoe arches were used on the top of the door openings, in arches of the arcades holding the ceiling, and in arch of mihrab squinch. A horseshoe arch is known by more than a name; as a horseshoe-arch or more than semi-circular. Muslim builders called the inflatable arch. Its use has generally prevailed in the buildings of the Islamic west [27]. Perhaps the motive for the prevalence of this type of arches in the buildings of the Islamic west, those characteristics are distinguishes, such as the strength of resistance and close cohesion. The horseshoe-arch's resistance to the impulse of strength does not rush out of the boundaries of the arch and helps hold its parts together. Also, the wall above the semi-circular arch is almost double twice the height of the wall above the horseshoe arch according to the length of the two legs of the horseshoe arch, 
compared to the semi-circular. Consequently, the strength of the horseshoe arch increases due to the lightness of the above load or the weight due to the low height of the wall above it. The lower wall height is followed by savings labor, construction materials, and cost [30]. The architect resorted to using the horseshoe arch to hold the ceiling in the mosque's arcades due to the short pillars with a height that does not exceed two-thirds of the human height. As the spandrel begins immediately after the pillar and lengthens, the arches start after a height of two meters in order to avoid a decrease in the ceiling. This feature is only available in the horseshoe arch. Also, the height of the horseshoe arch is not limited to its breadth [13]. In terms of construction, arches are usually built on wooden formwork (formations or packages). These formations are made from wooden pieces nailed to each other so that their outer surface forms the curvature of the arch [31].

\subsubsection{Ceilings}

Flat wooden ceilings were used to cover the mosque. Although flat ceilings are one of the least used types of ceilings in the buildings of the Islamic west compared to the gable and hierarchical ceilings due to the nature of the climatic conditions in this country, which is characterized by heavy rainfall for long periods of the year. Accordingly, domed ceilings prevent water from collecting at the top. It seems that the location of Tiznit city in the far south of Morocco, where it is less rainfall and the temperature is relatively higher, is what prompted the architecture to use flat ceilings to cover the mosque.

\subsection{Connection and movement ele- ments (Entrances)}

The elements of connection and movement are among the important elements in the institution. They link their parts to each other and connect the institution to the surrounding streets. Simply, these elements have a close relationship with the streets that overlook it [22]. This is done through the presence of an organizational arrangement in the movement between the voids from the outside to the inside. The contact between the inside and the outside is often done through gradual and sequential movements in a sequence that paves each of them to the other. This helps prayers gradually move from city life and prepares them progressively into the quiet inner private atmosphere of their spirituality to contribute to this arrangement in giving more emotional and privacy to these religious buildings [32]. Tiznit mosque is distinguished by comprising various entrances whose number, areas, and distribution have varied according to their function, size, layout, height of the mosque's walls and the surrounding streets and facilities. Some entrances directly connect the mosque to the street, while the others connect between prayer riwaqs and other mosque parts. The mosque contains four main entrances in order to facilitate the entry and exit of the prayers to and from the mosque. We note that the distribution of these entrances on the mosque's facades is linked to the streets and wide spaces overlooking the mosque. The four entrances were distributed on the north and west façades on Al-Jami square on Al-Bashawiya Street and on Al-Ain Al-Zarqa Street, which separates the mosque and the Kasbah of Ahgnaj. In the past, these entrances connected the mosque directly to the street, without being provided by stairs, whereas today the entrances are provided with a stair consisting of two or three steps. It is worth noting that the phenomenon of the absence of stairs in front of the entrances is not new but was found in all previous Moroccan buildings except for a few examples that have a stair in one or more of its entrances, such as the entrances to the Hassan mosque in Rabat, the entrance to the northwestern facade of the mosque of Andalusia in Fez [27], and the main entrance to the school of Abu al-Hasan al-Marini in Sala. The absence of stairs in front of the entrances of the buildings is because the floors of these buildings 
are at the same level as the streets overlooking them and the relative narrowness of the streets and roads of ancient Moroccan cities [13]. It is noted that the entrances of the mosque are distinct from the nature of its walls, followed by small dirgahs located inside the prominent entrance block so that they do not occupy a space in the riwaqs of prayer. The nature of the mosque planning and the absence of other outbuildings (katateb-sabile-mausoleum...) that perform other functions in the institution are also imposed on the small dirgahs and the absence of corridors following the entrances that distribute to the different units of the institution. It should be noted that the entrances to the mosque have fixed proportions in terms of width and height, as shown in tab. (1-a).

Table (1-a) The measurements of the mosque's

\begin{tabular}{ccc}
\hline $\begin{array}{c}\text { Width of the } \\
\text { entrance opening }\end{array}$ & $\begin{array}{c}\text { Height of the } \\
\text { entrance opening }\end{array}$ & $\begin{array}{c}\text { Ratio of width } \\
\text { to height }\end{array}$ \\
\hline $1.60 \mathrm{~m}$. & $2.65 \mathrm{~m}$. & $1: 1.66 \mathrm{~m}$. \\
$1.60 \mathrm{~m}$. & $2.65 \mathrm{~m}$. & $1: 1.66 \mathrm{~m}$ \\
$1.60 \mathrm{~m}$. & $2.40 \mathrm{~m}$. & $1: 1.50 \mathrm{~m}$ \\
$1.60 \mathrm{~m}$. & $2.65 \mathrm{~m}$. & $1: 1.66 \mathrm{~m}$ \\
\hline
\end{tabular}

The table shows that the width of the mosque's entrance holes is fixed at 1.60 meters and the height of the entrance holes reaches $2.65 \mathrm{~m}$. except for a single entrance. The height of the entrance is 2.40 $\mathrm{m}$. This is because this entrance is the only one with a segmental arch and not a horseshoe arch like the other entrances. Through the measurements of the mosque's entrances and by calculating its absorptive capacity, we find that the number of the entrances and their measurements are relatively appropriate to the mosque's area and the number of worshipers in normal conditions. However, in the case of the mosque's fullness of the worshipers at the end of it and in the case of the exit of all these worshipers at the same time, the number of entrances is insufficient and two more entrances are required, especially in the case of emergency. One of the studies illustrated that a two-meter wide entrance allows 23 persons in a minute to get out in normal conditions, where a man wearing his shoes slowly, without any motives of urgency. On the contrary, 50 persons can pass through the same hole in the case of an emergency in a minute. According to the recommendations of the National Fire Protection Association of the United States of America (AFPA), the time to vacate a place in the case of an emergency must not exceed three minutes [16]. By applying these proportions to the Tiznit Mosque, we find that the time required for all prayers to go out is normally 10.5 minutes and in the case of an emergency 4.86 minutes. This is evident from, tab. (1-b).

Table (1-b) The numbers and measurements of the mosque's entrances and its absorptive capacity.

\begin{tabular}{lc}
\hline Number of default prayer ${ }^{(\mathrm{b})}$ & 777 \\
\hline Number of entrances & 4 \\
Width of the entrance & $1.60 \mathrm{~m}$. \\
Number of people in a normal case & 74 \\
Number of people in emergency & 160 \\
Time required to exit normally & 10.5 minutes \\
Time required for an emergency exit & 4.86 minutes \\
\hline
\end{tabular}

The distribution of main entrances could be noted in the north and west facades where lead to western riwaq and northern riwaq - are helps to enter and exit to and from the mosque without skipping the worshipers. Moreover, the mosque comprises other entrances that lead to other places inside the mosque, such as room of orator, minbar, ablution area, minaret and library. The measurements of such entrances are consistent with their function. The width of the entrances of room of orator, room of minbar and minaret is 0.80 m., so they can be used by few persons, such as the muezzin or the orator. The width of the bookcase entrance is $1.10 \mathrm{~m}$., i.e. it is wider than the previous entrances and consistent with the number of scholars and sheikhs who use it. The location of these entrances is associated with the placement of the units that lead to them, which in turn were linked - in addition to their function - with some of the jurisprudential rules that organized their distribution, such as commitment to the right and nonskipping worshipers. The room of orator, 
room of minbar and bookcase are directly open to the qibla riwaq which allows the users to entry directly without skipping the worshipers. The entrances of room of orator, bookcase and the ablution area are on the right of mihrab.

\subsection{Ventilation and lighting elements}

\subsubsection{Windows}

There is a need for suitable ventilation and lighting openings for the prayer riwaqs in mosques, where a large number of people gather for periods that may belong in listening, recitation, or prayer, which necessitates suitable appropriate lighting and renewed air movement [33]. It is noticed that the mosque of Tiznit has few windows, as it only contains four upper windows. Perhaps, this is due to the cold weather in Morocco, especially in winter. As for the distribution of those windows, we notice that they are found in the eastern and western walls, and in exchange with the door openings, which helps with the court have a renewed movement of air inside the mosque, especially in summer, compatible with the wind direction in Tiznit, blowing from the northwestern. Also, we note that the distribution of windows in the east and west is compatible with the sun virtual movement from east to west, giving more ventilation and lighting to the mosque. The opening of windows in the upper section of the mosque's walls with the presence of the court and entrances has helped to create a moving and renewed aerial current inside the prayer riwaqs. This is a benefit of the physical properties of air, as hot air rises up and cold air falls down. The fact that the windows of the mosque are high increased the mosque's brightness. The depth at which side lighting (window lighting) can reach is limited by the height of the window and the height of the ceiling of the mosque. A window provides a useful light level of one and a half times the height of the window [34]. Since the ceiling of the mosque is high and all windows are high - as mentioned before - it provides a good amount of light that the riwaq for prayer need. Due to the low temperature and the frequent rainfall in Morocco, especially in winter, the architecture resorted to cover the mosque's windows with wood and glass to control the lighting and ventilation entering the mosque. The minaret also contained appropriate ventilation and lighting elements, which helped to perform its function in an optimal manner, as twelve windows were opened to light and ventilate the interior staircase. This helped the muezzin to ascend the minaret without stumbling. The vents are distributed in the four directions of the minaret to provide maximum ventilation and natural lighting in line with wind direction and sun virtual movement, and to distribute the lighting and ventilation appropriately throughout the minaret. The lack of houses adjacent to the mosque and its views on the courtyards and wide streets also helped distribute the holes of the minaret in its four sides without fear of detection damage.

\subsubsection{Court}

The orientation of buildings to the inside is an expression of the direction of human life that moved from the outer space to the inner courtyards. This reflects the social and religious ways of living for Muslims, as it provides hermitage and relief. Besides, courtyards and courts cool temperature as they help lifting hot air up [35]. Ventilation in Tiznit mosque was based on a court that provides ventilation and natural lighting for the mosque. This helped in reducing the number of windows on the outer walls and thus prevents cold air currents in winter and the bright sunshine in summer. Through the court or the courtyard, an air intake is carried out. When the court is exposed to sunlight, the weight of the hot air decreases and rises above the open court, in this case the cold air is drawn through the windows to replace the hot air [7]. This helps to create a heat balance between the external and internal climatic conditions of the building, i.e. the court is the medium between all external 
climatic conditions and the internal space or units of the building, through which a thermal exchange takes place throughout the day [13]. The architect covered the slots of the Riwaq for prayer overlooking the court with a fence of wood and glass with door shutters to control ventilation and lighting entering the mosque from the court.

\subsubsection{Entrances}

The mosque has four entrances, adding to the entrance that leads to a space in front of the ablution. These entrances, in addition to their role in facilitating connection and movement to and from the mosque, they provide the mosque with ventilation and lighting that the worshippers need. Especially if we notice that these entrances were directly connected between the Riwaqs for prayer and the streets, allowing them to bring a great deal of ventilation and lighting to the Riwaqs. The distribution of entrances in the north and west is compatible with the wind direction in Tiznit, blowing from the northwestern as we previously mentioned. These entrances are also large and high, increasing their ability to provide ventilation and lighting. Two wooden shutters were put on each entrance to control the amount of light and ventilation entering the mosque. If the above mentioned elements meet the aim of ventilation and lighting, the mosque's $5 \mathrm{~m}$. high ceiling provides adequate temperatures and ventilation to the worshippers. Studies have shown that the volume of air needed to be carried out inside the closed space is not less than $3 \mathrm{~m}^{3}$. of air per hour ${ }^{(\mathrm{c})}$ [16], and that each worshippers occupies an area of $0.75 \mathrm{~m}^{2}$. The ceiling of the Riwaqs for prayer should be at least 4 meters high. This was clearly achieved in the mosque, as its ceiling height is $5 \mathrm{~m}$. The use of horseshoe arch in the arcades has helped to rise to the ceiling. One of the most important features of these arches is the abundance of ventilation and lighting. It allows more light and air to pass through more than other arches. This advantage is probably the first factor in its popularity in the Western Muslim architecture. Due to cold weather in these countries, walls and ceilings of the Riwaqs for prayer do not contain holes, so they get light and air from the mosque's court. Architect used the horseshoe arch because its holes are wide and high -rather than other archesto allow air and light to get through [30].

\subsection{Elements of protection}

Elements of protection are the most important elements that formed the building. A building is originally established as a shelter and protection for human. Protection varies with the variety of effects. So there are elements for protection from weather (rain, direct sunlight, temperature), and protection from the eyes of the passersby or dangers in general. The protection elements from weather are represented in the outer walls and ceilings with its different types: flat, vaulted, a dome, etc. And the elements of protection against the eyes of the passersby are the outer walls, the inner walls and the wooden curtains [22]. To protect from weather, the buildings has established with their outer walls which are one of the most important elements of protection, as well as a structural element. Walls have protected those inside the building from heat and cold [36]. Which is reflected on the method of its establishment, such as increasing its thickness to prevent thermal conduction and acoustic insulation? or by increasing its height and regulating its openings for the protection from weather and other [24]. So the mosque's walls were thick and plastered with a layer of mortar to increase their durability and to protect against rain. The ceilings were also one of the methods used to protect the building and its attendants from rain and direct sunlight. As for the protection from the eyes of the people, walls have kept people inside the building from detection by increasing its height and regulating the openings to protect against the eyes of passersby [22]. As for the protection against general dangers is represented in pay attention to the entrances and make strong shutters to it. Therefore, each entrance in the mosque contained two wooden shutters. 


\section{Results}

The study showed the importance of the mosque location in Id Dalha district near the city center, so that it is close to every place in it to easily reachable. And it was near the blue waterhole to easily supply with water. Next to them was the Kasbah of Aghnaj the center of governance and administration at that time. It is a continuation of the phenomenon of adjacency among the government house, and the mosque. The study showed that the northern door in the western facade was added at a later time after building the mosque and was designated for women. The study also revealed that the Riwaqs for prayer occupied the largest portion of the mosque's area, to accommodate the largest number of worshippers. It also showed that the qiblah Riwaq is the largest riwaq, and it is distinguished that its breadth (length) is greater than its depth, which allows elongation of the first rows of the worshippers. This helps to accommodate the largest number, as the reward of praying in the front rows is greater. The study proved that the depth of the mihrab, which allows the imam to pray inside, provides behind him an extra row of worshippers. This increases the carrying capacity of the qiblah riwaq. In addition to that, this depth amplifies the voice of the imam. It is proved that the depth of the mihrab is a phenomenon followed in the mosques of the Islamic West. And it also showed that the mihrab's shape as a polygon is originally an Andalusian influence. The study indicated that the mosque does not contain a pew, contrary to the mosques of the Islamic West. The study also showed how high the minaret of the mosque is. Its height accomplishes several purposes: it is a sign of the existence of the mosque, the voice of the muezzin reaches the maximum distance possible, it limits the detailed view on the part of the muezzin to the neighboring houses and prevents detection damage, it can used in surveillance and reconnaissance.
And it also showed that the architect was in accordance with the choice of the location of the minaret away from the Riwaq for prayer in order not to take part of them. The minaret is also far away from the neighboring houses to prevent detection damage. The study proved that the engineering rule used in building the minaret is that its total height $=$ the circumference of its base. It also showed that the wooden pieces planted in the corners of the minaret were not used to climb on them during the restoration, as it was said, but it used as a local legacy. The study confirmed that the mosque's minbar was a moving one and was made of wood. This required a sheath for the minbar. In addition, the minbar was small enough to be easily moved, so it does not occupy a space in the qibla riwaq, and does not exhaust the worshippers sitting in the first row during listening to the Imam's speech. The study highlighted how thick the walls of the mosque and building it with locally available construction materials that ensured the strength of walls and its isolation for sound and heat. The study showed that the horseshoe arch was mainly used in the mosque. This is due to its many advantages. This guarantees the durability of the building and its quality, as it achieves better ventilation and lighting in the Riwaq for prayer. The study proved that the main entrance holes in the mosque have fixed proportions in terms of width and height. Also, their number and measurements were appropriate to the area of the mosque and the number of worshippers. And when distribute the entrances of the mosque take into account commitment to right and non-skipping worshipers. The study highlighted the small size of the court; so as not to take a large part of the riwaq for prayer, and to control the amount of ventilation entering the mosque, especially in winter. The study showed the lack of windows in the mosque. Some upper windows are only found, due to the cold nature of the 
country, especially in winter. The upper windows helped create a renewed airflow inside the mosque, especially in summer, in addition to providing more lighting in the Riwaq for prayer. Also, showed that the distribution of windows is compatible with the sun virtual movement and wind direction in Tiznit. The study showed the height of the ceiling of the mosque, which reached $5 \mathrm{~m}$. This achieved ventilation and lighting commensurate with the number of worshippers in the mosque.

\section{Discussion}

In this paper, we study and document the Great Mosque in Tiznit, because of its architectural features and great historical value in the Souss region in southern Morocco. The importance of research is due to it's the first study that shed light on the archaeological and architectural value of the mosque by describing and analyzing all the mosque's architectural and artistic elements. The study contributes to preserving and maintaining the mosque and highlighting its architectural, religious and scientific standing and value as one of the archaeological buildings in the city. This research is different from other researches that studied the mosque, like: Mešéla [37]; Boumzko \& Amerir [4] 'Alm'ālem 'altārīhīa dāhel 'almadīna 'al'atīka (historical monuments in the ancient city), which briefly referred to a number of archaeological building inside the city including the mosque, focusing on the scientific importance of the mosque without mentioning its architectural elements. Boumzko \& Amerir [4], mentioned that the wooden pieces planted in the min-aret were used during the conservation, whereas the current study mentioned that it was a local legacy. The importance of this research is due to the paucity of archaeological studies on Tiznit city. Most studies on the city - despite their few numbers - tackled some historical and geographical aspects of the city [2-6], or the reason behind the city's name [1]. This research agrees with study: 'Amerir, A.,
(2009), Mrāhel tataūr Tiznit mn qabila éla madena (Stages of the development of Tiznit from a village to a city), on the importance of the relationship of the mosque with the Kasbah and the water source [3]. The study opens the door to further studies of the rest of the archaeological monuments in Tiznit to highlight their historical and archaeological value, which increases the tourist attractions of the city.

\section{Conclusion}

This paper, describe, document, and analyze all architectural and decorative elements of the mosque. The research sheds light on the location, name, and history of Tiznit. The study contributes to preserving and maintaining the mosque and highlighting its architectural, religious and scientific standing and value as one of the archaeological buildings in the city.

\section{Endnotes}

(a) The mosques of the Islamic west distinguished depth of mehrab squinches, for example: the depth of mehrab squinches of Hafsid mosques in Tunisia reached $1.60 \mathrm{~m}$. and the depth of mehrab squinches in the islamic midle west reached $1.95 \mathrm{~m}$. such as mehrab of new mosque in Algere city, and the depth of mehrab squinches of Almohads mosques reached $3.50 \mathrm{~m}$. such as mehrab of Kasbah mosque in Marrakesh, and the depth of mehrab squinches of Morocco mosques in Saadi era ranged from $2.50 \mathrm{~m}$. to $3.25 \mathrm{~m}$. and in Andalus the depth of mehrab squinche of Qordova mosque is mor than $3 \mathrm{~m}$., and the depth of mehrab squinche of Almeria mosque reached $1.90 \mathrm{~m}$.

(b) The default space occupied by each worshipper is $0.75 \mathrm{~m}^{2}$. The default number of the mosque worshippers is reached by calculating the area of the Riwaq for prayer minus the space of the court and the arcades- the fact that the worshippers in Morocco and Andalusia do not pray between the columns and the pillars because this is jurisprudential disapproved- By dividing this space by the default 
space occupied by one worshipper, we reach the default number of worshippers that the mosque can contain.

(c) The analytical studies showed that air after inhalation consists of $16.5 \%$ oxygen, $4 \%$ carbon dioxide, $79.5 \%$ nitrogen and argon, which means that air must be continuously renewed at a constant rate consistent with the quality of activity within the building. It was found that an adult human needs 17.5 feet of air every hour. With simple activities, 100 feet per hour is needed. This shows the amount of air needed in the religious establishment crowded with worshippers [22].

\section{References}

[1] Omarī, A. (2009). 'Alqerảa 'altopnomīa wa aletomologīa le-kalemat Tiznit (Toponymic and Etomological Reading of the word Tiznit), in: Al Khanboby, A. (ed.) Tiznit Forum for the Coexistence of Cultures, Asmoun Association for Social, Cultural and Heritage Preservation, Tiznit, pp. 23-30.

[2] Nāfi, A. (1996). Eškalet maoqé Tiznit wa âlīat twasóha (The problematic location of the city of Tiznit and its expansion mechanisms), in: Bin Halima, H. (ed.) Tiznit Symp. and Its Desert, Faculty of Arts, Agadir, pp. 161-163.

[3] Amerir, A. (2009), Mrāḥel tațaūr Tiznit mn qabila'ela madena (Stages of the development of Tiznit from a village to a city), in: Al Khanboby, A. (ed.) Tiznit Forum for the Coexistence of Cultures, Asmoun Association for Social, Cultural and Heritage Pre-servation, Tiznit, pp. 19-22.

[4] Boumzko, A. \& 'Amerir, A. (2009). 'Alm ālem 'altārīhīa dāḩel 'almadīna 'al'atīka (historical monuments in the ancient city), in: Aámo, A. \& Al Manqosh, A. (eds.) Tiznit-Collective Memory, Tiznit Municipality, Morocco, pp. 55-60.

[5] 'Amerir, A. (2009). Tawze'e 'alsokān wa 'almsālek dahel 'aswār Tiznit (Population and tract distribution within the walls of Tiznit), in: Aámo, A. \& Al
Manqosh, A. (eds.) Tiznit Collective Memory, Tiznit Municipality, Morocco, pp. 84-85.

[6] 'Abū 'Al-Faraḥ, Y. (1996). Tiznit Ğog̀rāfĩan (Tiznit Geographically), in: Hegy, M. (ed.), Encyclopedia of Morocco, Vol. 8, Moroccan Association for Authorship, Salé Press, Rabat, pp. 2677-2678.

[7] Wazīì̄, Y. (2004). 'Al'emāra 'al'istāmīa wa 'albee'a (Islamic architecture and environment), Alam Al-maerifa 304, National Council for Culture, Arts and Letters, Kuwait.

[8] 'Al-Qādī, S., (2000), 'Altawğe'h ka'asās taṣmīmy le-'emārat 'almasāğed (Orientation as a design basis for mosque architecture), in: Mohamed, A. (ed.), The $4^{\text {th }}$ Int. Conf. on Architecture and Urbanization at the outset of the $3^{\text {rd }}$ millennium, Faculty of Engineering, Assiut Univ., Part 1, pp. 1-11.

[9] Aglan, A. (2019). Masğed 'al'obera b-madīnat 'alrebat (Al-Obera mosque in Rabat), J. of the Faculty of Arts, Sohag Univ., Vol. 51 (1), pp. 323-364.

[10]Maldonado, B. (2011). 'Emārat 'almsāğed fi 'al'andalus: Qurdoba wa msāğedha (Architecture of mosques in Andalusia: Cordoba and its mosques), Culture Authority for Heritage, Abu Dhabi, UAE.

[11] Tuama, N. (2016). Taṭawor 'alme'hrāb fī 'al'emāra 'al'islāmīa (Evolution of the mihrab in Islamic architecture), Dirasat J. Ammar Thaliji Univ., ALaghouat, Vol. 49, pp. 26-53.

[12]Daḥdūh, A. (2014). Dekat 'almobalgīn be'alğazā'er helāl 'al'a'hd 'aloțmānī The bench of muezzins in Algeria during the Ottoman period), CGUAA, Vol.17 (17), pp. 396-417.

[13]'Abū Rehāb, M., (2008), 'Al'amā'er 'aldīnīa wa 'alğnā'ezīa be-'almag்reb fì 'așr 'al'ašrāf 'als'adien (Religious and funerary architectures in Morocco in the era of al'ashraf alsaadi), Dar Alq-ahirat, Cairo.

[14]Othmān, M. (2002). 'Al'iielān bi'a'hkām 'albonīan le Ibn 'al-Ramī: (An 
Archaeological and Architectural Study), Dar Al-Wafaa Pub., Alexandria. [15]Bābaker, M. \& 'Abd 'Al-Latif, A. (2019). 'Altakween 'alğmālī le'alm'ednna fî̀ 'al'emāra 'al'islāmia fì 'Alsudān (The aesthetic composition of the minaret in Islamic architecture in Sudan), SUST J. of Humanities, Sudan Univ. of Science and Technology, Vol. 20 (2), pp. 181-196.

[16]Nofāl, M. (1999). 'Alm'aāeer 'altaṣmemīa le-'emārat 'almsāğed (Design criteria for mosques), in: Bin Șaleh, M. \& Alqoqāny, A. (eds.) Proc. of Symp. on Mosque Architecture, Vol. 5, College of Architecture \& Planning, King Saud Univ., KSA, pp. 75-94.

[17]Bīn Bellā, K. (2008). 'Almonšáāt 'aldīnīa be-'alğazā'er helāl 'al'a'hd 'aloțmāni (Religious buildings in Algeria during the Ottoman period), $\mathrm{Ph} . \mathrm{D}$, Institute of Archeology, Univ. of Algeria, Algeria.

[18]Othmān, M. \& 'Al-Emām, A. (1999), 'Emārat 'almsāğed fī Dū'o 'ala'ḥkām 'alfeq'hīa (Mosque architecture in response to sharia rules), in: Bin Șaleh, M. \& Alqoqāny, A. (eds.) Proc. of Symp. on Mosque Architecture, Vol. 8, College of Architecture \& Planning, King Saud Univ., KSA, pp. 133-160, (In Arabic).

[19]Ismāil, O. (1977). Derāsāt ğadeda fì 'alfonūn 'al'islāmīa wa 'alnokūš 'al'arabīa b-'almagreb 'al'aqșa (New studies in Islamic arts and Arabic inscriptions in Morocco), Dar Al Thaqafa, Beirut.

[20]The Tiznit great mosque, https:// www. visitagadir.z/en/tiznit-great-mosque, (2-2-2020).

[21]'Al-Zarkashi, M. (1999). 'iielām 'alsājid bi'a'ḥkām 'almsājid (Notification worshipers with the regulations of mosques), Supreme Council for Islamic Affairs, $5^{\text {th }}$ ed., Cairo.

[22]Othmān, M. (2000). Nazareat alwazefía be-al'amā'er aldīnīa almamlūkia albāqia be-madenat Alqāhera (Functional theory in the remaining Mamluk religious buildings in Cairo), Dar Al-Wafaa Pub., Alexandria.

[23]Aglan, A. (2011). Al-msāğed 'al-ğam'ea be-madinat Tunis fìal-'așr'Al-hafși (The great mosques in Tunis in Hafsid era), M.Sc., Islamic Archaeology dept., Faculty of Arts, Sohag Univ., Egypt.

[24]Othmān, M. (1990). 'Adoā'a 'ala ahmīat 'al'enhāa'a fî tāreh 'al'emāra 'al'istāmīa, (Spotlight on the importance of construction in the history of Islamic architecture), Al-Osoor, Vol. 5 (2), pp. 231-255.

[25]Bin Nomān, I. (2010). Albenā'a bealtorāb fi belād almağreb al'islāmy: Teqneat altāpia namozagn (Building with mud in the Islamic Moroccotapia technique as a model), Historical Kan Periodical, Vol. 10, pp. 19-26.

[26]' Abū Rehāb, M. (2011). 'Aswār madinnat Taroudant be-'almaġreb 'al'aqșa, (Walls of Taroudant City - Morocco), J. of History and the Future, Minia Univ., Vol.49 pp. 79-151, (In Arabic).

[27]'Al-Kaḥlāwī, M. (1986). 'Al'emāra 'al'islāmīa fì 'algarb 'al'islāmī: Amā'er 'almoahdìen 'aldīnīa fì 'almagreb (Islamic architecture in the Islamic west: the Almohad religious buildings in Morocco), Ph.D, Islamic Archaeology dept., Faculty of Archeology, Cairo Univ., Egypt.

[28]Balbas, T. (1971). Alfan almorābety wa almoa'hedy (Almoravid and Almohad art), Dar Al-Maarif, Cairo.

[29]'Al-Sadlān, S., (1999), 'Alḍawābet 'alšar'eīa le-'emārat 'almsāğed (Jurisprudence control for mosque Architecture), in: Bin Șaleh, M. \& Alqoqāny, A. (eds.) Proc. of Symp. on Mosque Architecture, Vol. 8, College of Architecture \& Planning, King Saud Univ., KSA, pp. 1-32.

[30]Fikry, A. (1936). 'Almasğed 'al̆̄ām'e be-'Alqaīrwān (The great mosque of Kairouan), Dar Al-Maaref Press, Cairo.

[31]'Azab, K. (1999). 'Alhșāa'es 'alm'emārīa wa 'alfanīa le-msāğed madīnat Fowa (Architectural and technical characteristics of Fowa city mosques), in: Bin Șaleḥ, M. \& Alqoqāny, A. (eds.) 
Proc. of Symp. on Mosque Architecture, Vol. 7, College of Architecture \& Planning, King Saud Univ., KSA, pp. 33-72.

[32] 'Abū Ġonaimah, A. (1999). ' Almrākez 'al'islāmīa fì Oropa (Islamic centers in Europe), in: Bin Șaleh, M. \& Alqoqāny, A. (eds.) Proc. of Symp. on Mosque Architecture, Vol. 7, College of Architecture \& Planning, King Saud Univ., KSA, pp. 1-16.

[33] Yahya, N. (2000). 'Alfatahāt wa 'almzhar 'al'aām le-'almbāny 'aldīnīa (Openings and the general appearance of religious buildings), in: Mohamed, A. (ed.) The $4^{\text {th }}$ Int. Conf. on Architecture and Urbanization at the outset of the $3^{\text {rd }}$ millennium, Faculty of Engineering, Assiut Univ., Egypt, part 1, pp. 27-37.

[34]'Al-Raddādi, T. (1999). 'Alm'aāeer 'altașmīmīa le-'al'iedā'a 'altabī'eīa fì 'almsāğed (Design criteria for day lighting in mosques), in: Bin Șaleḥ, M.
\& Alqoqāny, A. (eds.) Proc. of Symp. on Mosque Architecture, Vol. 6, College of Architecture \& Planning, King Saud Univ., KSA, pp. 13-24.

[35]Mahrān, A. (1999). ' Alm'aāīer 'altahtîtīa wa 'al'ososs 'altașmīmīa le-'almsāğed fì 'almudon 'al'islāmīa (Planning criteria and design standards for mosques in the Islamic cities), in: Bin Șaleh, M. \& Alqoqāny, A. (eds.) Proc. of Symp. on Mosque Architecture, Vol. 6, College of Architecture \& Planning, King Saud Univ., KSA, pp. 161-180.

[36]Shahbī, A. (2010). 'Alğām'e 'al'atīq be-Ġerdāīa (algazā'er) namozag leal'emāra al'ibādeia (The ancient mosque in Ghardaia (Algeria) is an example of Ibadi architecture), CGUAA, Vol. 13 (13), pp. 1259-1280.

[37]Mešéla, F. (2019). Madenat Tiznit (Tiznit city),https://mawdoo3.com/ \%D9\%85\% D8\%AF\%D9\%8A\%D9\%86\%D8\%A9_ $\% \mathrm{D} 8 \% \mathrm{AA} \% \mathrm{D} 9 \% 8 \mathrm{~A} \% \mathrm{D} 8 \% \mathrm{~B} 2 \% \mathrm{D} 9 \%$ 86\%D9\%8A\%D8\%AA,(30-10-2019). 